\title{
Completion Thyroidectomy in Patients Diagnosed with Papillary Thyroid Cancer: Is There a Predictive Factor for Contralateral Lobe Tumor?
}

\author{
(Demal Kaya, (1) Emre Bozkurt, (1) Sinan Ömeroğlu, (1) Mehmet Mihmanlı, (1) Mehmet Uludağ \\ Department of General Surgery, University of Health Sciences, Istanbul Sisli Hamidiye Etfal Training and \\ Research Hospital, Istanbul, Turkey
}

\begin{abstract}
Objectives: Completion thyroidectomy (CT) is defined as the removal of the residual thyroid tissue in the case of detected malignancy after lobectomy for an indeterminate or non-diagnostic biopsy. Factors such as tumor diameter, aggressive histology, extrathyroidal spread, and positive surgical margin in papillary thyroid cancer (PTC) constitute CT indications. However, the type of surgery is controversial especially in patients with a tumor diameter of 1-4 cm. Determination of predictive factors for contralateral lobe tumors (CLTs) in PTC may be helpful for rough or excessive treatment of patients with this common thyroid pathology.

The aim of the present study was to determine the predictive factors and rate of detection of CLTs after CT in patients with papillary thyroid carcinoma after lobectomy.

Methods: Medical records of patients who underwent lobectomy with the final histological diagnosis of papillary thyroid carcinoma for the study period 2011 to 2016 were reviewed. Demographic data of the patients, diameter, multicentricity and subtype of tumor, extrathyroidal spread, and vascular invasion rate were obtained. Patients were divided into 2 groups as final histological examination after $\mathrm{CT}$ revealed benign (Group 1) and malignant (Group 2).

Results: Data of 49 patients were retrospectively analyzed during the study period. The female-to-male ratio was 33/16. The mean age of the patients was 47.59 (23-77) years. Groups 1 and 2 consisted of 30 and 19 patients, respectively. No significant difference was found between the two groups regarding demographic data and tumor characteristics.

Conclusion: Despite the fact that we have not been detecting any predictive factor in predicting the presence of tumor on the contralateral lobe in our study, the detection of a tumor on the contralateral lobe is frequent.

Keywords: Cancer; completion thyroidectomy; lobectomy; papillary thyroid carcinoma; pathology; predictive factor.

Please cite this article as "Kaya C, Bozkurt E, Ömeroğlu S, Mihmanlı M, Uludağ M. Completion Thyroidectomy in Patients Diagnosed with Papillary Thyroid Cancer: Is There a Predictive Factor for Contralateral Lobe Tumor?. Med Bull Sisli Etfal Hosp 2018;52(4):262-267".
\end{abstract}

T hyroid nodules are one of the most common endocrine pathologies in adult populations and can be diagnosed by physical examination (4\%-8\%), ultrasonographic examination (10\%-41\%), and autopsy (50\%). ${ }^{[1]}$ Though the majority of these nodules are benign, thyroid carcinoma is detected in approximately $5 \%$ of the cases. ${ }^{[2,3]}$ Papillary thyroid cancer (PTC) is the most frequent histological subtype of thyroid cancer, and the incidence of PTC increases over the years. ${ }^{[4]}$ It usually has an indolent course, rarely showing aggressive behavior. Although PTC prognosis is good,

Address for correspondence: Emre Bozkurt, MD. İstanbul Şişli Hamidiye Etfal Eğitim ve Araştırma Merkezi, Sağlık Bilimleri Üniversitesi,

Genel Cerrahi Anabilim Dalı, Istanbul, Turkey

Phone: +90 5324619339 E-mail: dr.emrebozkurt@gmail.com

Submitted Date: April 20, 2018 Accepted Date: June 05, 2018 Available Online Date: December 28, 2018

${ }^{\circ}$ Copyright 2018 by The Medical Bulletin of Sisli Etfal Hospital - Available online at www.sislietfaltip.org

This is an open access article under the CC BY-NC-ND license (http://creativecommons.org/licenses/by-nc/4.0/). 
PTC should be evaluated carefully because of the potential for distant metastasis. The cancer-specific mortality rate is $<5 \%$ of patients with PTC, and most patients have an excellent prognosis. ${ }^{[5]}$

The removal of the residual thyroid tissue in the case of detected malignancy after lobectomy has practical benefits regarding patients' treatment. ${ }^{[6]}$ Completion thyroidectomy (CT) is the conversion of the process to total thyroidectomy (TT) by the removal of the residual thyroid tissue after subtotal thyroidectomy. The reason for preferring lobectomy is to avoid unnecessary thyroidectomies in patients with fine needle aspiration (FNA) biopsy that is suspiciously malignant or those that are indeterminate following FNA. ${ }^{[5,6]}$

Thyroid lobectomy is the recommended initial surgical approach in patients with solitary, cytologically indeterminate nodule, atypia of undetermined significance/follicular lesion of undetermined significance (AUS/FLUS), or follicular neoplasm/suspicious for follicular neoplasm (FN/ SFN) according to the 2015 American Thyroid Association (ATA) guidelines. However, this approach may be modified according to the clinical or sonographic characteristics of the patient and patient preference or molecular tests. ${ }^{[7]}$ The reason for the recommendation of $\mathrm{CT}$ for patients with histology of AUS/FLUS is suspicious malignant risk of $5 \%-15 \%$ according to the Bethesda classification.

CT for PTC decreases local recurrence, improves survival, and facilitates the follow-up. ${ }^{[8]}$

In the case of cancer detection after lobectomy, it is controversial to perform an intervention to the contralateral lobe. ${ }^{[6,8]}$ In patients with malignant histopathology, no accurate method or criterion can help to understand whether malignancy is present in the contralateral lobe. We aimed to determine the predictive factors and rate of detection of contralateral lobe tumors (CLTs) after CT in patients with detected PTC after lobectomy.

\section{Methods}

Medical records of patients who underwent lobectomy for nodular goiter without a history of known malignancy with a final histological diagnosis of PTC in the study period 2011 to 2016 were reviewed. Demographic data of the patients, diameter, multicentricity and subtype of tumor, extrathyroidal spread, and vascular invasion rate were obtained. All patients were evaluated by a radiologist experienced in neck ultrasonography (USG) for the detection of the remaining tissue and lymph nodes. The present study was conducted in accordance with the 1964 Declaration of Helsinki.

In our study, CT was performed to patients with an extrathyroidal spread, a history of radiation to the neck, tumor $>4 \mathrm{~cm}$ in diameter, aggressive variant of papillary thyroid carcinoma, and the presence of multiple nodules or nodule in the contralateral lobe. We perform CT to patients with a tumor diameter $<1 \mathrm{~cm}$ after lobectomy for an extrathyroidal spread and aggressive variant of papillary thyroid carcinoma. Patients with aggressive variant papillary cancer, tumor spread to the lateral compartment, and extrathyroidal spread for tumors $>4 \mathrm{~cm}$ were treated with a central, a lateral neck dissection, or both. After lobectomy, 16 patients whose pathology result reported as the classical or follicular variant of PTC with a tumor $<1 \mathrm{~cm}$ without extrathyroidal spread, and whose follow-up USG had no pathological findings in the opposite lobe or neck were followed up in a non-operative manner within the preference of the patient.

Patients $<18$ years old, with complementary thyroidectomies following bilateral subtotal thyroidectomy, and without total complementary thyroidectomy were excluded from the study. Informed consent was obtained from all patients.

Data were obtained by a review of the retrospectively maintained database. Patients were divided into 2 groups as final histological examination after CT revealed benign (Group 1) and malignant (Group 2). Variables that could be predictive factors, such as age, tumor diameter, multicentricity, subtype, vascular invasion, and extrathyroidal spread, were compared between these two groups. We perform CT to patients with a tumor diameter $<1 \mathrm{~cm}$ after lobectomy for extrathyroidal spread and aggressive variant of papillary thyroid carcinoma.

All analyzes were performed using the Statistical Product and Service Solutions (SPSS) software package (version 21.0; SPSS IBM, Armonk, NY, USA) at a 95\% confidence level and $p<0.05$ significance level. Quantitative variables were expressed as mean and standard deviation. Qualitative variables were expressed as number and percentages.

\section{Results}

Of the 217 patients who underwent lobectomy in our clinic, 40 had PTC, whereas 3 had medullary thyroid carcinoma. The incidence rate of cancer was $19.8 \%(n=43)$ in our series. PTC incidence was detected as $18.4 \%(n=40)$. CT was performed for 37 out of 40 PTC patients. While 12 of whom had lobectomy at different clinics and 37 had lobectomy in our clinic, a total of 49 patients whose histopathological examination was reported as PTC after lobectomy were enrolled in the study. The female-to-male ratio was $33 / 16$. The mean age of the patients was 47.59 (23-77) years. Indications of the first surgical procedure were benign causes (cosmesis, compression symptoms, and $>3.5 \mathrm{~cm}$ nodule) of nodular thyroid disease for 35 patients and AUS/FLUS or FN/SFN for 
14 patients. Subtypes of PTC were the follicular variant for 24 (48.9\%) patients, the classic variant for 24 (48.9\%) patients, and the tall cell variant for $1(2 \%)$ patient. The average time between the 2 surgical procedures for patients included in the study was 93 (54-130) days. In addition to CT, as a result of patients' neck USG examinations and clinical evaluations, two of the patients had unilateral central neck dissection, and one had bilateral central and lateral neck dissection. While patients with unilateral central neck dissection had 3 and 1 positive lymph nodes, respectively, patients with bilateral central and lateral neck dissection had 6 out of 22 positive lymph nodes. While histopathological examination of the TT materials revealed no malignancy in 30 (61.2\%) patients in the contralateral lobe (Group 1), it showed malignancy for 19 (38.8\%) patients (Group 2). Table 1 shows the age of the patients, tumor subtype after the first operation, diameter, multicentricity of the tumor, extrathyroidal spread, and vascular invasion rates. Table 2 lists the age, subtype, diameter, multicentricity of the tumor, extrathyroidal spread, and vascular invasion rates. Micropapillary
Table 1. Demographic and histopathological features of patients after lobectomy (first operation)

\begin{tabular}{lcc}
\hline & Mean \pm SD & Min-Max \\
\hline Age (years) & $47.0 \pm 13.3$ & $23-77$ \\
Tumor diameter (cm) & $2.17 \pm 1.27$ & $0.2-5.5$ \\
& $\mathbf{n}$ & $\%$ \\
\hline Vascular invasion & & \\
$\quad$ No & 39 & 79.6 \\
$\quad$ Yes & 10 & 20.4 \\
Extrathyroidal spread & & \\
$\quad$ No & 43 & 87.7 \\
$\quad$ Yes & 6 & 12.3 \\
Subtype & & \\
$\quad$ Follicular variant & 24 & 48.9 \\
$\quad$ Classic variant & 24 & 2.0 \\
$\quad$ Tall cell variant & 1 & \\
After CT* benign/malignant (B/M) & & 61.2 \\
ratio for contralateral lobe & & 38.8 \\
$\quad$ Benign & 30 & \\
$\quad$ Malignant & 19 & \\
\hline
\end{tabular}

$\mathrm{CT}$ : Completion thyroidectomy.

Table 2. Comparison of demographic and histopathological features between groups

\begin{tabular}{|c|c|c|c|c|c|}
\hline & \multicolumn{2}{|c|}{$\begin{array}{c}\text { Group } 1 \\
\text { Mean } \pm \text { SD (Min-Max) }\end{array}$} & \multicolumn{2}{|c|}{ Group 2} & $\mathbf{p}$ \\
\hline Age (Years) & \multicolumn{2}{|c|}{$47.7 \pm 15.2(23-77)$} & \multicolumn{2}{|c|}{$45.8 \pm 10.1(31-63)$} & 0.630 \\
\hline \multirow[t]{2}{*}{ Tumor diameter (cm) } & \multicolumn{2}{|c|}{$2.17 \pm 0.97(0.2-4)$} & \multicolumn{2}{|c|}{$2.18 \pm 1.66(0.4-5.5)$} & 0.313 \\
\hline & $\mathbf{n}$ & $\%$ & $\mathbf{n}$ & $\%$ & \\
\hline \multicolumn{6}{|l|}{ Age (Years) } \\
\hline$<45$ & 15 & 50.0 & 8 & 42.1 & 0.590 \\
\hline$>45$ & 15 & 50.0 & 11 & 57.9 & \\
\hline \multicolumn{6}{|l|}{$\begin{array}{l}\text { Tumor diameter }(\mathrm{cm}) \\
\text { after first operation }\end{array}$} \\
\hline$\leq 1$ & 4 & 13.3 & 6 & 31.6 & 0.123 \\
\hline $1-4$ & 23 & 76.7 & 9 & 47.4 & \\
\hline$\geq 4$ & 3 & 10 & 4 & 21.1 & \\
\hline \multicolumn{6}{|l|}{$\begin{array}{l}\text { Multicentricity } \\
\text { after first operation }\end{array}$} \\
\hline No & 20 & 66.7 & 12 & 63.2 & 0.801 \\
\hline Yes & 10 & 33.3 & 7 & 36.8 & \\
\hline \multicolumn{6}{|l|}{$\begin{array}{l}\text { Vascular invasion } \\
\text { after first operation }\end{array}$} \\
\hline No & 24 & 80.0 & 15 & 78.9 & 0.929 \\
\hline Yes & 6 & 20.0 & 4 & 21.1 & \\
\hline \multicolumn{6}{|l|}{$\begin{array}{l}\text { Extrathyroidal spread } \\
\text { after first operation }\end{array}$} \\
\hline No & 27 & 90.0 & 16 & 84.2 & 0.547 \\
\hline Yes & 3 & 10.0 & 3 & 15.8 & \\
\hline \multicolumn{6}{|l|}{$\begin{array}{l}\text { Subtype } \\
\text { after first operation }\end{array}$} \\
\hline Follicular variant & 16 & 53.3 & 8 & 42.1 & 0.442 \\
\hline Classic variant & 14 & 46.7 & 10 & 52.6 & \\
\hline Tall cell variant & 0 & 0.0 & 1 & 5.3 & \\
\hline
\end{tabular}


carcinoma was detected in 6 (31.5\%) patients who had malignancy on the contralateral lobe in the second operation.

There was no significant difference between the 2 groups regarding the mean age $(p=0.590)$. While 7 out of $19(36.8 \%)$ patients who were diagnosed with malignancy had multicentricity, 10 out of 30 (33.3\%) patients without malignant histopathology had multicentricity in the first operation.

Since multicentricity rates are similar between the groups, there was no significant difference between the 2 groups regarding multicentry as a predictive factor $(p=0.801)$. There was no significant difference in the comparison of the subtype and diameter of the tumor, extrathyroidal spread, and vascular invasion rates between the groups as a predictive factor for CLT (Table 2).

\section{Discussion}

Indications for benign causes of thyroidectomies are usually compression of the trachea or esophagus, cosmetic concern, and overt hyperthyroidism. Lobectomy is usually a satisfactory procedure for both, unilateral benign pathologies of the thyroid and when there is no pathology in the contralateral lobe in cases with AUS/FLUS and FN after FNA. Thyroid cancer has been reported as 3\%-16.6\% after thyroidectomy for benign diseases of the thyroid..$^{[9,10]}$ Güner et al. reported the incidence as $3.37 \%(n=9)$ for incidentally detected PTC in 314 patients operated for multinodular goiter. ${ }^{[1]}$

In our study, the rate of thyroid cancer after unilateral lobectomy was detected as $19.8 \%$. Indications for the first operations of all patients with CT were diagnosis of AUS/ FLUS or SN/SFN after FNA and lobectomy for benign indications of nodular goiter for 14 and 35 patients, respectively. Recently, it has been reported that incidentally detected PTC increased after thyroidectomies due to benign thyroid pathologies. Lombardi et al. indicated that $42 \%$ of the 933 PTCs identified in endemic goiter areas are incidentally detected. ${ }^{[12]}$ While the incidence of incidental malignancy after unilateral thyroidectomies was $19.8 \%(n=43)$ in our study, the PTC rate was detected as $18.4 \%(n=40)$.

Histopathological evaluation of patients requiring CT revealed high rates of residual tumors. ${ }^{[13,14]}$ The residual tumor rate has been reported between $29 \%$ and $56.3 \%$ in various studies. ${ }^{[14-17]}$ Since detection of multicentric tumor is increasing the likelihood of CLT, CT is recommended even when the tumor size is $<1 \mathrm{~cm} .{ }^{[17]}$ The high recurrence and residual tumor rates led the surgeons to perform more $\mathrm{CT}$. Histopathological examination of CT materials revealed malignancy for 19 (38.8\%) patients in the contralateral lobe in our study. Among 17 lobectomies with multicentric tumor, the incidence of malignancy was detected as $36.8 \%$, which was similar to the rate of patients without CLT
(33.3\%). Although multicentricity was reported as a factor increasing the rate of detection of CLT in the literature, in our study, 20 (40.8\%) patients with detected multicentricity in the previous operation did not have a CLT after CT. This situation requires a detailed investigation of whether multicentricity alone is an indication for TT.

Thyroid malignancy consists of heterogeneous tumor groups with a broad spectrum of biological behavior. The appropriate treatment usually results in high survival rates. There is a continuing debate on the reasons for the incompleteness of studies with large randomized series or longterm follow-up, comparing the methods and treatment options for these tumors. ${ }^{[18,19]}$

While TT has been reported to reduce local recurrence rate, improve survival, and facilitate follow-up in differentiated thyroid cancers, inadequate tissue ablation is an independent factor that adversely affects prognosis. ${ }^{[8]}$ The leading causes of $\mathrm{CT}$ in our study were optimizing the radioiodine ablation of the remaining thyroid tissue and ensuring better follow-up postoperatively and consequently contributing to recurrence and survival. The removal of the remaining thyroid tissue will provide practical benefits regarding monitoring and treatment of patients with PTC.

While Pacini et al. found cancer at the residual thyroid tissue in 80 (44\%) out of 182 patients who underwent CT for the diagnosis of PTC after lobectomy, they reported that they detected lymph node metastasis in 10 cases that did not detect cancer in the remaining tissue. ${ }^{[20]}$ As a result of this research, if the diagnosis of PTC is made before surgery, TT should be performed, and if it is done after lobectomy, it should be completed to TT. ${ }^{[20]}$

CT has not been adequately demonstrated to improve survival, but multifocal tumors necessitate $\mathrm{CT}^{\left[{ }^{[21]}\right.}$

In particular, multicentricity is higher in the contralateral thyroid lobe in patients with multicentric papillary microcarcinomas. ${ }^{[17]}$ Since multicentricity rates were similar in our groups, multicentricity was not helpful in detecting cancer in the remaining tissue as a predictive factor.

Pellegriti et al. examined 299 cases with PTC $<1.5 \mathrm{~cm}$ in size and found that of the patients, $30 \%$ have multicentric tumor and lymph node metastases, $20 \%$ have extrathyroidal spread, and $3 \%$ have distant metastases and also found that tumor aggressiveness increases as the tumor diameter increases. ${ }^{[22]}$ In our study, we found that the tumor diameter was not a significant predictive factor in helping to understand the presence of CLT.

When histological subtypes of PTC were examined, tall cell and diffused sclerosing variant were more aggressive than classical and follicular variant PTC. ${ }^{[23]}$ Follicular variant PTCs 
are smaller than classical variant PTCs and have a lower regional lymph node metastasis rate. ${ }^{[24,25]}$

Badr Ibrahim et al. reported the rate of CLT as $48 \%$ after TT in a study conducted on 97 patients. In the present study, the presence of multicentricity and aggressive subtype in the first operation was found to be more important than the initial tumor size for the decision to $\mathrm{CT}^{\left[{ }^{[26]}\right.}$

In patients with lobectomy, the remaining tissue is clinically relevant, as it is cancerous or not. Since this may lead to incomplete or excessive treatment and associated complications, the development of a predictive factor for these patients will contribute to this issue.

In the 2015 ATA guidelines, there is no suggested predictive factor, but CT indications are presented for patients with detected cancer after lobectomy. These indications are tumor size of $\geq 4 \mathrm{~cm}$, extrathyroidal spread, and poor histological variant.

All the patients in our study were directed to the nuclear medicine clinic after CT. In three patients who had high thyroglobulin levels during follow-up after radioactive iodine ablation therapy, distant metastases were detected with positron emission tomography-computed tomography, and these patients were again treated with radioactive iodine ablation therapy. A patient with extrathyroidal spread of $>4 \mathrm{~cm}$ had a $1 \mathrm{~cm}$ peripheral lymphadenopathy in the neck detected with USG performed after detection of high blood triglyceride ( $\mathrm{Tg}$ ) level in postoperative follow-up, and due to Tg washout result in favor of recurrence, excision was performed.

\section{Conclusion}

In our study, $79 \%$ of patients with tumors $<1 \mathrm{~cm}$ and $1-4 \mathrm{~cm}$ had CLT. When we examined all of our patients, the CLT rate was high (38.8\%). Nevertheless, no significant predictive factor for CLT was detected. Discussions on the border of over-treatment and appropriate treatment are still ongoing. We think that this is an issue that needs further investigation in larger series for clarification.

\section{Disclosures}

Ethics Committee Approval: The present study was conducted in accordance with the 1964 Declaration of Helsinki.

Peer-review: Externally peer-reviewed.

Conflict of Interest: None declared.

Authorship contributions: Concept - C.K., E.B., S.Ö., M.M.; Design - C.K., E.B., S.Ö., M.U.; Supervision - C.K., M.M., M.U.; Materials - C.K., E.B., S.Ö.; Data collection \&/or processing - C.K., E.B., S.Ö.; Analysis and/or interpretation - C.K., E.B., S.Ö., M.M.; Literature search - C.K., E.B., S.Ö., M.M., M.U.; Writing - C.K., E.B.; Critical review - C.K., S.Ö., M.M., M.U.

\section{References}

1. Frates MC, Benson CB, Charboneau JW, Cibas ES, Clark OH, Coleman BG, et al. Management of thyroid nodules detected at US: Society of Radiologists in Ultrasound consensus conference statement. Radiology 2005;237:794-800. [CrossRef]

2. Hegedüs L. Clinical practice. The thyroid nodule. N Engl J Med 2004;351:1764-71. [CrossRef]

3. Brito JP, Yarur AJ, Prokop LJ, Mclver B, Murad MH, Montori VM. Prevalence of thyroid cancer in multinodular goiter versus single nodule: a systematic review and meta-analysis. Thyroid 2013;23:449-55. [CrossRef]

4. Davies L, Welch HG. Current thyroid cancer trends in the United States. JAMA Otolaryngol Head Neck Surg 2014;140:317-22. [CrossRef]

5. Orosco RK, Hussain T, Brumund KT, Oh DK, Chang DC, Bouvet M. Analysis of age and disease status as predictors of thyroid cancerspecificmortality using the Surveillance, Epidemiology, and End Results database. Thyroid 2015;25:125-32. [CrossRef]

6. Kılıç AY, Sayek İ. Diferansiye tiroidkarsinomlarının tedavisinde tamamlayıcı tiroidektominin yeri. İşgör $A$, editor. Tiroid Hastalıkları ve Cerrahisi. İstanbul: Nobel Tıp Kitabevi; 2002. p.405-9

7. Haugen BR, Alexander EK, Bible KC, Doherty GM, Mandel SJ, Nikiforov YE, et al. 2015 American Thyroid Association Management Guidelines for AdultPatients with Thyroid Nodules and Differentiated Thyroid Cancer: The American Thyroid Association Guidelines Task Force on Thyroid Nodulesand Differentiated Thyroid Cancer. Thyroid 2016;26:1-133. [CrossRef]

8. Mazzaferri EL. An overview of the management of papillary and follicular thyroid carcinoma. Thyroid 1999;9:421-7. [CrossRef]

9. Miccoli P, Minuto MN, Galleri D, D'Agostino J, Basolo F, Antonangeli $L$, et al. Incidental thyroid carcinoma in a large series of consecutive patientsoperated on for benign thyroid disease. ANZ J Surg 2006;76:123-6. [CrossRef]

10. Efremidou El, Papageorgiou MS, Liratzopoulos N, Manolas KJ. The efficacy and safety of total thyroidectomy in the management of benignthyroid disease: a review of 932 cases. Can J Surg 2009;52:39-44.

11. Güner A, Kaya MA, Aydın A, Bozkurt S, Kılıç YE, Güler K, et al. Multinodüler guatr nedeniyle ameliyat edilen hastalarda insidental tiroid karsinomu. Turk J Surg 2007;23:87-91

12. Lombardi CP, Bellantone R, De Crea C, Paladino NC, Fadda G, Salvatori $\mathrm{M}$, et al. Papillary thyroid microcarcinoma: extrathyroidal extension, lymph nodemetastases, and risk factors for recurrence in a high prevalence of goiterarea. World J Surg 2010;34:1214-21.

13. Pasieka JL, Thompson NW, McLeod MK, Burney RE, Macha M. The incidence of bilateral well-differentiated thyroid cancer found at completion thyroidectomy. World J Surg 1992;16:711-6. [CrossRef]

14. Alzahrani AS, Al Mandil M, Chaudhary MA, Ahmed M, Mohammed GE. Frequency and predictive factors of malignancy in residual thyroid tissueand cervical lymph nodes after partial thyroidectomy for differentiatedthyroid cancer. Surgery 2002;131:443-9. [CrossRef] 
15. Kim ES, Kim TY, Koh JM, Kim YI, Hong SJ, Kim WB, et al. Completion thyroidectomy in patients with thyroid cancer who initially underwent unilateral operation. Clin Endocrinol (Oxf) 2004;61:145-8.

16. Grigsby PW, Reddy RM, Moley JF, Hall BL. Contralateral papillary thyroid cancer at completion thyroidectomy has no impacton recurrence or survival after radioiodine treatment. Surgery 2006;140:1043-7. [CrossRef]

17. Pitt SC, Sippel RS, Chen H. Contralateral papillary thyroid cancer: does size matter? Am J Surg 2009;197:342-7. [CrossRef]

18. Sadler GP, Wheeler MH. The thyroid gland. Farndon JR, editor. Endocrine Surgery. Saunders; 2003. p.39-87.

19. Schwab R, Wieler H, Birtel S, Ostwald-Lenz E, Kaiser KP, Becker HP. Confronting the practice of surgery on differentiated thyroid cancer with current guidelines in Germany. A multicenter trial. [Article in German]. Nuklearmedizin 2005;44:185-91. [CrossRef]

20. Pacini F, Elisei R, Capezzone M, Miccoli P, Molinaro E, Basolo F, et al. Contralateral papillary thyroid cancer is frequent at completionthyroidectomy with no difference in low- and high-risk patients. Thyroid 2001;11:877-81. [CrossRef]

21. Lefevre JH, Tresallet C, Leenhardt L, Jublanc C, Chigot JP, Menegaux F. Reoperative surgery for thyroid disease. Langenbecks
Arch Surg 2007;392:685-91. [CrossRef]

22. Pellegriti G, Scollo C, Lumera G, Regalbuto C, Vigneri R, Belfiore A. Clinical behavior and outcome of papillary thyroid cancers smaller than $1.5 \mathrm{~cm}$ in diameter: study of 299 cases. J Clin Endocrinol Metab 2004;89:3713-20. [CrossRef]

23. Kazaure HS, Roman SA, Sosa JA. Aggressive variants of papillary thyroid cancer: incidence, characteristicsand predictors of survival among 43,738 patients. Ann Surg Oncol 2012;19:1874-80.

24. Ertek S, Yılmaz NC, Cicero AF, Vurupalmaz Ö, Demiröz AS, Erdoğan G. Increasing diagnosis of thyroid papillary carcinoma follicular variant in south-east Anatolian region: comparison of characteristics of classical papillary and follicular variant thyroid cancers. Endocr Pathol 2012;23:157-60. [CrossRef]

25. Ozdemir D, Ersoy R, Cuhaci N, Arpaci D, Ersoy EP, Korukluoglu $B$, et al. Classical and follicular variant papillary thyroid carcinoma: comparison of clinical, ultrasonographical, cytological, and histopathological features in 444 patients. Endocr Pathol 2011;22:58-65. [CrossRef]

26. Ibrahim B, Forest VI, Hier M, Mlynarek AM, Caglar D, Payne RJ. Completion thyroidectomy: predicting bilateral disease. J Otolaryngol Head Neck Surg 2015;44:23. [CrossRef] 